\title{
Influence of iron plaque and cultivars on antimony uptake by and translocation in rice (Oryza sativa L.) seedlings exposed to $\mathrm{Sb}(\mathrm{III})$ or $\mathrm{Sb}(\mathrm{V})$
}

\author{
Yanchao Huang • Zheng Chen • Wenju Liu
}

Received: 15 April 2011 / Accepted: 19 August 2011 / Published online: 3 September 2011

(C) Springer Science+Business Media B.V. 2011

\begin{abstract}
Background and Aims Characteristically baseline levels of $\mathrm{Sb}$ in the environment are low, but problematic local elevation trends arise from anthropogenic activities such as mining and incineration. Arsenic (analog of $\mathrm{Sb}$ ) accumulation by rice can be reduced by iron $(\mathrm{Fe})$ plaque. A hydroponic experiment was conducted to investigate whether Fe plaque could reduce the uptake and translocation of different $\mathrm{Sb}$ species in different rice cultivars.

Methods After Fe plaque on rice roots was induced in solution containing $0,0.2,0.4,0.7,1.2,2.0 \mathrm{mM} \mathrm{Fe}^{2+}$ for $24 \mathrm{~h}$, seedlings were transferred into nutrient solution with $20 \mu \mathrm{M} \mathrm{Sb}(\mathrm{V})$ or $\mathrm{Sb}(\mathrm{III})$ for $3 \mathrm{~d}$.

Results About 60-80\% (Sb(III) treatment) and 40$60 \%(\mathrm{Sb}(\mathrm{V})$ treatment) of the total $\mathrm{Sb}$ accumulated in Fe plaque. There was a significant correlation between the concentrations of $\mathrm{Sb}$ and $\mathrm{Fe}$ on the root
\end{abstract}

Responsible Editor: Henk Schat.

Y. Huang $\cdot$ Z. Chen

Research Center for Eco-environmental Sciences, Chinese

Academy of Sciences,

Beijing 100085, China

W. Liu $(\bowtie)$

College of Resources and Environmental Sciences,

Agricultural University of Hebei,

Baoding 071000, China

e-mail: liuwj@hebau.edu.cn

W. Liu

e-mail: wenjuliu71@gmail.com surface. A similar relationship was observed in roots and shoots. Cultivar (Jiahua 1) formed the most Fe plaque, had the highest $\mathrm{Fe}$ associated $\mathrm{Sb}$ sequestration but the lowest $\mathrm{Sb}$ concentration in the root interior. Conclusions Fe plaque may act as a 'buffer' for $\mathrm{Sb}$ (V) and $\mathrm{Sb}$ (III) in the rhizosphere, and cultivars played an important role in the different species $\mathrm{Sb}$ uptake and translocation.

Keywords Antimony species · Translocation · Iron plaque $\cdot$ Rice Cultivars

\section{Introduction}

Ranking $62^{\text {nd }}$ in crustal abundance the trace element Antimony is commonly found in soils at concentrations between 0.2 and $0.3 \mathrm{mg} \mathrm{kg}^{-1}$ (Rish 2004). It has no biological function and is non-essential to plants (He and Yang 1999; Miravet et al. 2005). However, antimony is a potent mammalian toxin (Gebel 1997), and considered as a priority pollutant by USA (USEPA 1999) and EU (Council of the European Communities 1976). It has been reported that high concentrations of antimony persist at some sites of the world due to human activities such as mining and incineration (Baroni et al. 2000; Hammel et al. 2000; Flynn et al. 2003). In the latest decades, global fluxes of $\mathrm{Sb}$ have increased at least 10-fold (Irina et al. 2011). Plants growing in these Sbcontaminated areas can accumulate antimony from 
the soil (Murciego et al. 2007). China is rich in antimony mine resources. Most antimony mines are located in Hunan and Guangxi Provinces ( $\mathrm{He}$ and Yang 1999). Rice is the staple food for the people in these areas. So, more attentions should be paid to the uptake by and translocation of antimony in rice from these regions. Furthermore, the toxicity of $\mathrm{Sb}$ in the environment strongly depends on the speciation. The general order of the toxicity for $\mathrm{Sb}$ species is given as: organoantimonials (e.g. methylated species)<antimonates $(\mathrm{Sb}(\mathrm{V}))<$ antimonites ( $\mathrm{Sb}(\mathrm{III})$ (Gebel 1997; He and Yang 1999; Krachler et al. 2001; Filella et al. 2002), which is similar to arsenic (As) (Susan et al. 2010). Since inorganic $\mathrm{Sb}$ species are more abundant than organic species in the natural systems (Filella et al. 2009), $\mathrm{Sb}(\mathrm{V})$ and $\mathrm{Sb}(\mathrm{III})$ were used in our experiments.

As a waterlogged plant, rice is usually cultivated in an anaerobic and chemically reduced environment (Colmer 2003). The concentrations of metal(loid) ions in soil, such as $\mathrm{Fe}^{2+}, \mathrm{Mn}^{2+}, \mathrm{Cu}^{2+}$, $\mathrm{Ni}^{2+}$, arsenite can significantly increase in anaerobic conditions (Armstrong 1967). Rice development can be seriously affected if these reduced metal ions are taken up in excess by roots. Radial oxygen loss (ROL) from roots to the rhizosphere is considered to be essential for detoxification of these phytotoxins by direct oxidation or oxidizing aerobic microorganisms maintained in the rhizosphere region (Armstrong and Armstrong 2005).

Most aquatic plant species, including rice, can form iron plaque on their roots by oxidizing $\mathrm{Fe}(\mathrm{II})$ to $\mathrm{Fe}(\mathrm{III})$. Some reports have shown that iron plaque can act as a barrier to the uptake of heavy metals, such as $\mathrm{Cu}, \mathrm{Cd}, \mathrm{Mn}$ and Ni (Greipsson 1995; Wang and Peverly 1999; Batty et al. 2000). However, a number of reports conclude the opposite, with Fe plaque found to increase the uptake of toxic and nutrient elements (Zhang et al. 1998; Ye et al. 2001). Therefore the overall effect of Fe plaque on the uptake of toxic and nutrient elements may be related to the amounts of Fe plaque (Zhang et al. 1998).

Arsenic accumulation by rice can be affected by iron plaque (Liu et al. 2004a, b; Chen et al. 2005). Because $\mathrm{Sb}$ and As are metalloids belonging to Group 15 of the periodic table of elements, they share some toxicological and chemical properties with As (Casiot et al. 2007; Susan et al. 2010), antimony accumulation by rice may be also influenced by the amounts of Fe plaque formed on the root surface.
Consequently the aims of our study were 1) to investigate whether $\mathrm{Fe}$ plaque could affect the different forms of antimony accumulation in different rice cultivars; 2) to reveal the relationship between $\mathrm{Fe}$ and $\mathrm{Sb}$ in $\mathrm{Fe}$ plaque and rice tissues; 3 ) to investigate the translocation of $\mathrm{Sb}(\mathrm{III})$ and $\mathrm{Sb}(\mathrm{V})$ in different rice cultivars.

\section{Materials and methods}

Plant cultivation

Seeds of three rice (Oryza sativa L.) cultivars (Yangdao 6(YD), Nongken 57(NK), Jiahua 1(JH)) were used in our experiment. Seeds were sterilized in $30 \% \mathrm{H}_{2} \mathrm{O}_{2}$ solution for $15 \mathrm{~min}$, followed by thoroughly washing with distilled water. After germination in moist perlite for 3 weeks, uniform seeding were selected and transported to PVC pots $(7.5 \mathrm{~cm}$ diameter and $14 \mathrm{~cm}$ height, one plant per pot). Each pot contained $500 \mathrm{ml} \mathrm{1/3}$ strength nutrient solution which is modified from Hewitt (1966). The composition of the full strength nutrient solution contained $50 \mu \mathrm{M} \quad \mathrm{Fe}(\mathrm{II})$-ethylenediaminetetraacetic acid (EDTA), $10 \mu \mathrm{M} \mathrm{H}_{3} \mathrm{BO}_{4}, 1.0 \mu \mathrm{M} \mathrm{ZnSO}_{4} \cdot 7 \mathrm{H}_{2} \mathrm{O}$,

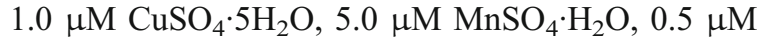
$\mathrm{Na}_{2} \mathrm{MoO}_{4} \cdot 2 \mathrm{H}_{2} \mathrm{O}, 0.2 \mu \mathrm{M} \mathrm{CoSO}_{4} \cdot 7 \mathrm{H}_{2} \mathrm{O}, 5 \mathrm{mM}$ $\mathrm{NH}_{4} \mathrm{NO}_{3}, 2 \mathrm{mM} \mathrm{K} \mathrm{SO}_{4}, 4 \mathrm{mM} \mathrm{CaCl} 2,1.5 \mathrm{mM}$ $\mathrm{MgSO}_{4} \cdot 7 \mathrm{H}_{2} \mathrm{O}$ and $1.3 \mathrm{mM} \mathrm{KH} \mathrm{PO}_{4}$. The solution $\mathrm{pH}$ value was adjusted to 5.5 using $0.1 \mathrm{M} \mathrm{KOH}$ or $\mathrm{HCl}$. The nutrient solution was changed every 3 to 4 days.

All pots were placed in a controlled environment growth chamber with a $14 \mathrm{~h}$ light period (260$350 \mathrm{mM} \mathrm{m}^{-2} \mathrm{~s}^{-1}$ ) and a $10 \mathrm{~h}$ dark period. The temperature was kept at $25^{\circ} \mathrm{C}$ during the day and $20^{\circ} \mathrm{C}$ during the night. The relative humidity was $70 \%$.

\section{Experimental treatments}

After the rice seedlings grew in nutrient solution for 3 weeks, iron plaque was induced on the roots surface. Before the iron plaque induction, all plants were washed and put into deionized water for $12 \mathrm{~h}$ to minimize any disturbance from other elements to iron. They were transferred into $500 \mathrm{ml}$ solution with $0,0.2,0.4,0.7,1.2$, and $2.0 \mathrm{mM}$ of ferrous ion for $24 \mathrm{~h}\left(\mathrm{Fe}^{2+}\right.$ as $\mathrm{FeSO}_{4} \cdot 7 \mathrm{H}_{2} \mathrm{O}, \mathrm{pH}$ 5.5). These treatments were called $\mathrm{Fe} 0, \mathrm{Fe} 0.2$, $\mathrm{Fe} 0.4, \mathrm{Fe} 0.7$, Fe1.2, and Fe2.0, respectively. 
After iron plaque induction, seedlings were transferred into $1 / 3$ strength normal nutrient solution for $48 \mathrm{~h}$. Then they were transferred in nutrient solution with $20 \mu \mathrm{M} \mathrm{Sb}$ (III) (Potassium antimony(III) oxide tartrate hemihydrate; $\left.\mathrm{KSbC}_{4} \mathrm{H}_{4} \mathrm{O}_{7} \cdot 1 / 2 \mathrm{H}_{2} \mathrm{O}\right)$ or $\mathrm{Sb}(\mathrm{V})$ (Potassium hexahydroxoantimonate $(\mathrm{V}) ; \mathrm{KSb}(\mathrm{OH})_{6}$ ) for $3 \mathrm{~d}$. The solutions were renewed every day to avoid changes in Sb species. Each treatment had three replicates, and there were 108 pots in all.

\section{DCB extraction of iron plaque}

At harvest, all roots of seedlings were washed three times with deionized water. Then iron plaque on root surfaces were extracted using dithionite-citratebicarbonate (DCB), as described by Liu et al. (2004a). Roots of each seedling were cut and incubated for $1 \mathrm{~h}$ at room temperature $\left(20-25^{\circ} \mathrm{C}\right)$ in $30 \mathrm{ml}$ solution containing $0.125 \mathrm{M}$ sodium bicarbonate $\left(\mathrm{NaHCO}_{3}\right)$ and $0.03 \mathrm{M}$ sodium citrate $\left(\mathrm{Na}_{3} \mathrm{C}_{6} \mathrm{H}_{5} \mathrm{O}_{7} \cdot 2 \mathrm{H}_{2} \mathrm{O}\right)$ with the addition of $0.5 \mathrm{~g}$ sodium dithionite $\left(\mathrm{Na}_{2} \mathrm{~S}_{2} \mathrm{O}_{4}\right)$. Roots were rinsed three times with deionized water which was added to the DCB extracts. The final solution was made up to $50 \mathrm{ml}$ with deionized water. After DCB extraction, roots and shoots were oven-dried at $70^{\circ} \mathrm{C}$ for $72 \mathrm{~h}$ and weighed.

Plant digestion and analysis

For determination of total antimony in the roots and shoots, homogenized samples $(0.1-0.2 \mathrm{~g})$ were weighed into a $50 \mathrm{ml}$ volume centrifuge tube and soaked in $2 \mathrm{ml}$ of high purity $\mathrm{HNO}_{3}$. After standing overnight at room temperature $\left(20-25^{\circ} \mathrm{C}\right)$, the samples were randomized and subjected to microwave digestion (Mars,Matthews Inc., USA). The digestion program was run as follows: $55^{\circ} \mathrm{C}$ for $10 \mathrm{~min}, 75^{\circ} \mathrm{C}$ for $10 \mathrm{~min}, 95^{\circ} \mathrm{C}$ for $30 \mathrm{~min}$ with $5 \mathrm{~min}$ ramp time between each stage. The digested samples were diluted to $40 \mathrm{ml}$ with deionized water and then filtered to remove impurities. This method was reported by Sun et al. (2008) for determining total As concentrations.

A reagent blank and standard reference plant material (Bush branches and leaves, GBW07603 from the National Research Center for Standards in China) were included, to verify the accuracy and precision of the digestion procedure and subsequent analysis recovery. The concentrations of $\mathrm{Sb}$ in the DCB- extracts and Fe were measured by ICP-OES. The concentrations of $\mathrm{Sb}$ in the acid digests were measured by ICP-MS. The recovery rates of $\mathrm{Fe}$ and $\mathrm{Sb}$ were $85 \pm 5 \%$ and $162 \pm 8 \%$ (means $\pm \mathrm{SD}, n=6$ ) in this experiment, respectively.

Statistical analysis

Analyses of variance (ANOVA) were performed using SPSS 16.0.

\section{Results}

Iron plaque formation

Iron plaque was clearly visible on the root surface after $24 \mathrm{~h} \mathrm{Fe}^{2+}$ incubation. The amounts of iron plaque differed between cultivars and increased with increasing of $\mathrm{Fe}^{2+}$ concentrations in the pretreatment solutions, while levels kept stable when the increment of iron concentration reached a cultivar specific threshold (Fig. 1). Cultivar YD got the lowest DCB-Fe concentration and maintained a steady Fe level in treatments above Fe0.4. For cultivars NK and $\mathrm{JH}$, the amounts of $\mathrm{Fe}$ in plaque increased between $\mathrm{Fe} 0$ - Fe 0.7 , and then kept stable. Moreover, the amounts of $\mathrm{Fe}$ in plaque for three cultivars followed the trend of $\mathrm{JH}>\mathrm{NK}>\mathrm{YD}(P<0.05)$ at each iron level.

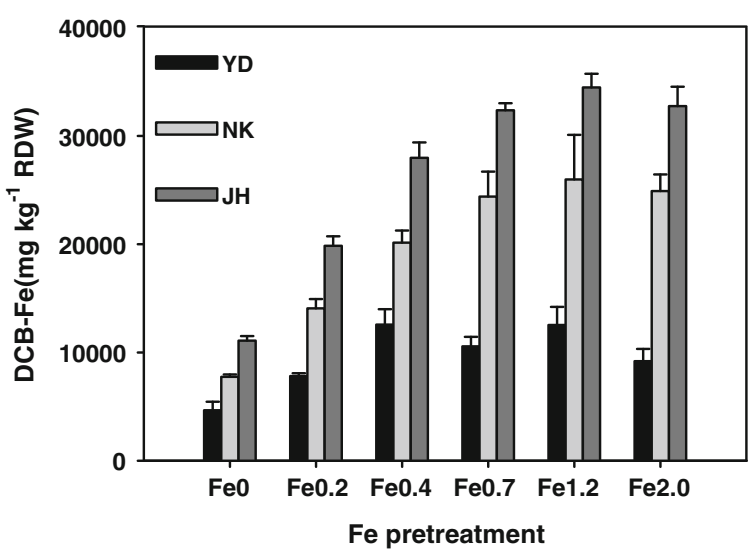

Fig. 1 The influence of $\mathrm{Fe}$ concentrations in pretreatment solution on the amounts of iron plaque formed on the root surface of three cultivars: Yangdao 6 (YD), Nongken 57 (NK) and Jiahua $1(\mathrm{JH})$. (means $\pm \mathrm{SE}, n=6)$ 
$\mathrm{Sb}$ accumulation in iron plaques

Antimony concentrations in DCB extracts increased significantly with $\mathrm{Fe}$ concentration for the three cultivars when $\mathrm{Sb}$ (III) (Fig. 2) and $\mathrm{Sb}(\mathrm{V})$ (Fig. 3) were supplied. Cultivars, $\mathrm{Sb}$ species and $\mathrm{Fe}^{2+}$ concentrations in the pretreatment solutions had significant effects on $\mathrm{Sb}$ concentrations in iron plaques (Table 1). Sb accumulated in the iron plaques when $\mathrm{Sb}$ (III) supplies were much higher than those of $\mathrm{Sb}(\mathrm{V})$ for three cultivars (Table 1). Cultivars had a strong influence on $\mathrm{Sb}$ concentrations accumulated in iron plaque when $\mathrm{Sb}$ (III) was supplied but there was no significant effect with $\mathrm{Sb}(\mathrm{V})$.

Effect of iron plaque on uptake and translocation of antimony

$\mathrm{Fe}^{2+}$ concentrations in pretreatment solutions had no significant effect on $\mathrm{Sb}$ concentrations in roots but had influence in shoots with $\mathrm{Sb}$ (III) supplied for three cultivars (Table 2). When the iron concentrations increased, fluctuation of $\mathrm{Sb}$ concentrations in shoots was observed. $\mathrm{Sb}$ concentrations in roots increased significantly with the increment of $\mathrm{Fe}^{2+}$ concentrations in pretreatment solution for cultivars YD and $\mathrm{NK}$ in $\mathrm{Sb}(\mathrm{V})$ treatment. But no change was found for cultivar JH. Iron concentrations in pretreatment solution had no effect on the $\mathrm{Sb}$ concentrations in shoots with $\mathrm{Sb}(\mathrm{V})$ addition (Table 2$)$. Sb accumulation in roots and shoots when $\mathrm{Sb}(\mathrm{III})$ supplied was much higher than that when $\mathrm{Sb}(\mathrm{V})$ supplied for three cultivars (Table 2).

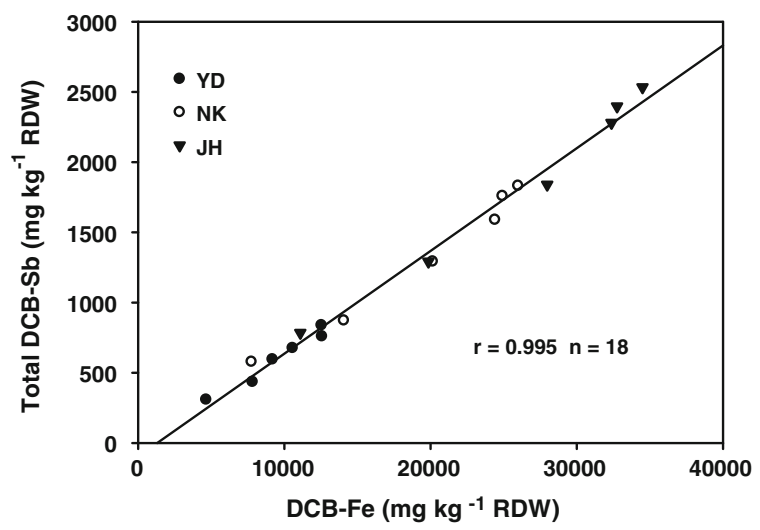

Fig. 2 Correlation between concentrations of $\mathrm{Fe}$ and $\mathrm{Sb}$ in DCB extracts $(P<0.01)$. Plants were exposed to nutrient solution with $\mathrm{Sb}$ (III) for $72 \mathrm{~h}$
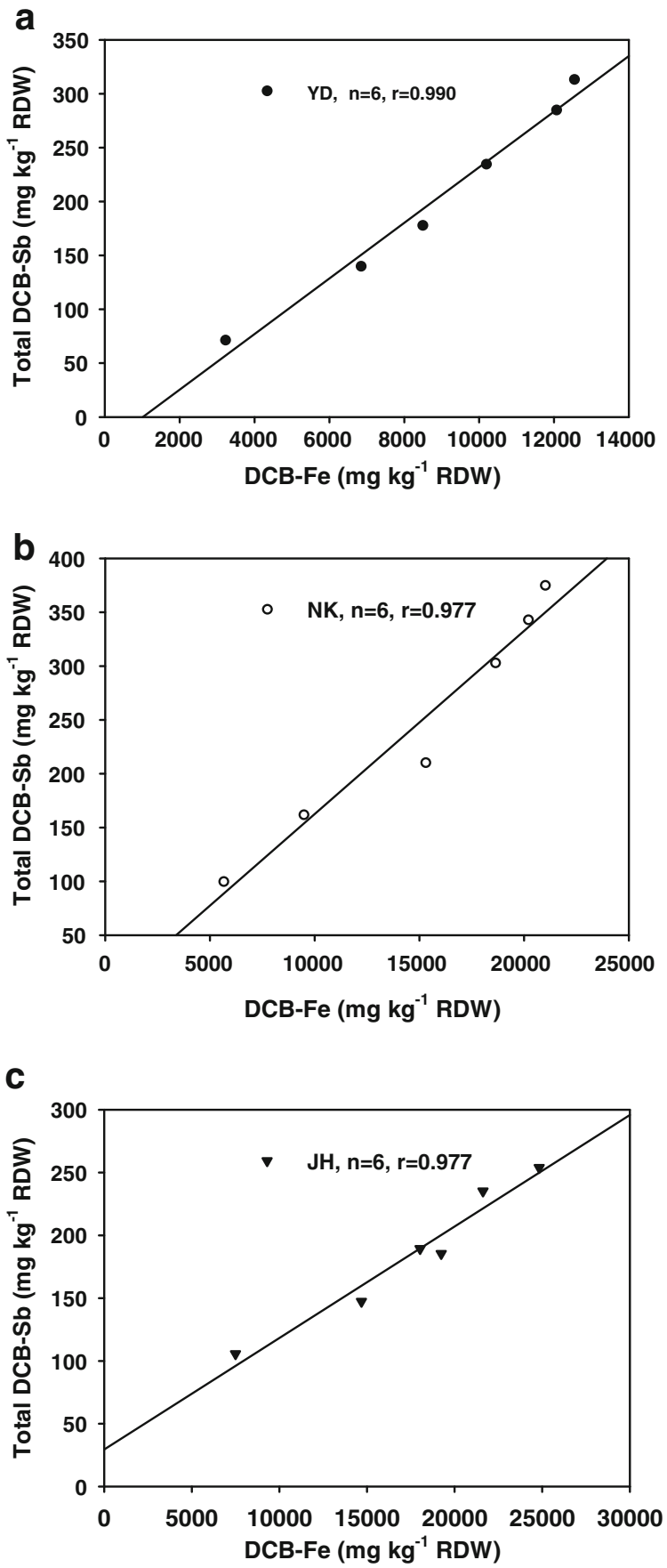

Fig. 3 Correlation between concentrations of $\mathrm{Fe}$ and total $\mathrm{Sb}$ in DCB extracts $(P<0.01)$ (a: cultivar $\mathrm{YD}$; b: cultivar NK; : cultivar JH). Plants were treated by $\mathrm{Sb}(\mathrm{V})$ for $72 \mathrm{~h}$

Cultivars had no effect on the Sb concentrations in shoots either with $\mathrm{Sb}(\mathrm{V})$ supplied or with $\mathrm{Sb}(\mathrm{III})$. However, the opposite conclusion was made in roots. Cultivar JH make the lowest $\mathrm{Sb}$ concentration in root 
Table $1 \mathrm{Sb}$ concentrations in DCB extracts of three rice cultivars treated by different Sb species and the analysis of variance (means \pm $\mathrm{SE}, n=3)$

\begin{tabular}{|c|c|c|c|c|c|c|}
\hline \multirow[t]{2}{*}{ Fe Pretreatment } & \multicolumn{2}{|c|}{ DCB-Sb (mg kg ${ }^{-1}$ RDW) } & \multirow{2}{*}{$\begin{array}{l}\mathrm{Sb}(\mathrm{III}) \text { treatment } \\
\mathrm{JH}\end{array}$} & \multicolumn{2}{|c|}{ DCB-Sb (mg kg ${ }^{-1}$ RDW) } & \multirow{2}{*}{$\begin{array}{l}\mathrm{Sb}(\mathrm{V}) \text { treatment } \\
\mathrm{JH}\end{array}$} \\
\hline & YD & NK & & YD & NK & \\
\hline $\mathrm{Fe} 0$ & $308 \pm 26.1 \mathrm{c}$ & $578 \pm 15.1 \mathrm{~d}$ & $784 \pm 43.3 \mathrm{~d}$ & $71.2 \pm 5.16 \mathrm{~d}$ & $99.6 \pm 2.05 \mathrm{~d}$ & $105 \pm 8.43 \mathrm{~d}$ \\
\hline $\mathrm{Fe} 0.2$ & $435 \pm 19.1 \mathrm{c}$ & $872 \pm 5.28 \mathrm{~cd}$ & $1291 \pm 66.8 \mathrm{c}$ & $139 \pm 11.4 \mathrm{c}$ & $161 \pm 13.6 \mathrm{c}$ & $147 \pm 3.64 \mathrm{c}$ \\
\hline $\mathrm{Fe} 0.4$ & $760 \pm 87.9 \mathrm{ab}$ & $1292 \pm 110 b c$ & $1839 \pm 96.6 b$ & $177 \pm 17.5 \mathrm{c}$ & $210 \pm 14.1 \mathrm{c}$ & $185 \pm 5.44 b$ \\
\hline $\mathrm{Fe} 0.7$ & $675 \pm 52.1 \mathrm{ab}$ & $1589 \pm 150 \mathrm{ab}$ & $2279 \pm 52.4 \mathrm{a}$ & $234 \pm 14.7 b$ & $302 \pm 30.3 b$ & $235 \pm 7.13 \mathrm{a}$ \\
\hline $\mathrm{Fe} 1.2$ & $838 \pm 126 a$ & $1832 \pm 295 \mathrm{a}$ & $2532 \pm 106 a$ & $284 \pm 2.85 \mathrm{a}$ & $342 \pm 25.4 \mathrm{ab}$ & $189 \pm 4.44 b$ \\
\hline $\mathrm{Fe} 2.0$ & $595 \pm 66.2 b$ & $1759 \pm 120 \mathrm{a}$ & $2396 \pm 126 a$ & $313 \pm 20.1 \mathrm{a}$ & $374 \pm 18.4 \mathrm{a}$ & $253 \pm 12.2 \mathrm{a}$ \\
\hline \multicolumn{7}{|l|}{ Analysis of Variance } \\
\hline Cultivars (C) & & $P<0.01$ & & & NS & \\
\hline $\mathrm{Fe}$ & & $P<0.01$ & & & $P<0.01$ & \\
\hline $\mathrm{Sb}$ Speciation (Sb) & & $P<0.01$ & & & $P<0.01$ & \\
\hline $\mathrm{C} \times \mathrm{Fe}$ & & $P<0.01$ & & & $P<0.01$ & \\
\hline $\mathrm{C} \times \mathrm{Sb}$ & & $P<0.01$ & & & $P<0.01$ & \\
\hline $\mathrm{Fe} \times \mathrm{Sb}$ & & $P<0.01$ & & & $P<0.01$ & \\
\hline $\mathrm{C} \times \mathrm{Fe} \times \mathrm{Sb}$ & & $P<0.01$ & & & $P<0.01$ & \\
\hline
\end{tabular}

Table $2 \mathrm{Sb}$ concentrations in roots and shoots of three rice cultivars treated by different $\mathrm{Sb}$ species and the analysis of variance (means \pm SE, $n=3$ )

\begin{tabular}{|c|c|c|c|c|c|c|c|}
\hline \multirow[t]{2}{*}{ Sb Treatment } & \multirow[t]{2}{*}{ Fe Pretreatment } & \multicolumn{3}{|c|}{$\mathrm{Sb}$ in roots $\left(\mathrm{mg} \mathrm{kg}^{-1} \mathrm{RDW}\right)$} & \multicolumn{3}{|c|}{$\mathrm{Sb}$ in shoots (mg kg $\left.{ }^{-1} \mathrm{SDW}\right)$} \\
\hline & & YD & NK & $\mathrm{JH}$ & YD & NK & $\mathrm{JH}$ \\
\hline \multirow[t]{6}{*}{$\mathrm{Sb}(\mathrm{III})$} & $\mathrm{Fe} 0$ & $270 \pm 13.3 \mathrm{a}$ & $332 \pm 26.3 a$ & $204 \pm 10.9 a$ & $15.4 \pm 2.87 \mathrm{ab}$ & $16.3 \pm 2.56 \mathrm{a}$ & $10.7 \pm 2.29 \mathrm{ac}$ \\
\hline & $\mathrm{Fe} 0.2$ & $301 \pm 28.9 \mathrm{a}$ & $307 \pm 27.8 \mathrm{a}$ & $203 \pm 2.78 \mathrm{a}$ & $12.9 \pm 1.19 \mathrm{ab}$ & $11.7 \pm 1.38 \mathrm{ab}$ & $6.77 \pm 0.30 \mathrm{c}$ \\
\hline & $\mathrm{Fe} 0.4$ & $292 \pm 10.3 \mathrm{a}$ & $300 \pm 10.1 \mathrm{a}$ & $220 \pm 1.54 \mathrm{a}$ & $17.1 \pm 1.99 a$ & $7.07 \pm 0.84 b$ & $8.04 \pm 0.84 b c$ \\
\hline & $\mathrm{Fe} 0.7$ & $357 \pm 11.8 \mathrm{a}$ & $299 \pm 26.7 \mathrm{a}$ & $194 \pm 22.7 \mathrm{a}$ & $14.5 \pm 3.77 \mathrm{ab}$ & $10.4 \pm 0.74 b c$ & $13.1 \pm 1.25 \mathrm{a}$ \\
\hline & $\mathrm{Fe} 1.2$ & $337 \pm 19.6 a$ & $331 \pm 45.2 \mathrm{a}$ & $210 \pm 23.6 a$ & $8.76 \pm 1.60 b$ & $12.9 \pm 1.11 \mathrm{ac}$ & $11.8 \pm 0.56 \mathrm{ab}$ \\
\hline & $\mathrm{Fe} 2.0$ & $331 \pm 47.1 \mathrm{a}$ & $335 \pm 41.3 \mathrm{a}$ & $219 \pm 2.68 \mathrm{a}$ & $9.39 \pm 2.37 b$ & $15.9 \pm 2.81 \mathrm{ac}$ & $13.4 \pm 1.92 \mathrm{a}$ \\
\hline \multirow[t]{6}{*}{$\mathrm{Sb}(\mathrm{V})$} & $\mathrm{Fe} 0$ & $117 \pm 4.13 \mathrm{c}$ & $191 \pm 6.99 b$ & $156 \pm 3.98 \mathrm{ab}$ & $7.43 \pm 0.95 \mathrm{a}$ & $8.64 \pm 0.80 \mathrm{a}$ & $3.77 \pm 0.38 \mathrm{a}$ \\
\hline & $\mathrm{Fe} 0.2$ & $149 \pm 24.3 b c$ & $200 \pm 22.9 b$ & $154 \pm 1.33 \mathrm{ab}$ & $10.2 \pm 1.22 \mathrm{a}$ & $10.1 \pm 1.06 \mathrm{a}$ & $5.04 \pm 0.10 \mathrm{a}$ \\
\hline & $\mathrm{Fe} 0.4$ & $164 \pm 4.91 b$ & $224 \pm 15.3 \mathrm{ab}$ & $149 \pm 2.55 b$ & $8.00 \pm 1.18 \mathrm{a}$ & $6.70 \pm 0.23 \mathrm{a}$ & $3.13 \pm 2.30 \mathrm{a}$ \\
\hline & $\mathrm{Fe} 0.7$ & $184 \pm 12.2 \mathrm{ab}$ & $249 \pm 18.8 \mathrm{a}$ & $171 \pm 9.15 \mathrm{a}$ & $9.65 \pm 0.47 \mathrm{a}$ & $7.67 \pm 0.16 \mathrm{a}$ & $8.61 \pm 1.33 \mathrm{a}$ \\
\hline & $\mathrm{Fe} 1.2$ & $174 \pm 5.01 \mathrm{~b}$ & $251 \pm 4.56 \mathrm{a}$ & $162 \pm 4.11 \mathrm{ab}$ & $8.49 \pm 0.83 a$ & $7.98 \pm 1.09 \mathrm{a}$ & $5.42 \pm 0.88 \mathrm{a}$ \\
\hline & $\mathrm{Fe} 2.0$ & $213 \pm 9.77 \mathrm{a}$ & $250 \pm 10.5 \mathrm{a}$ & $153 \pm 9.20 \mathrm{ab}$ & $8.48 \pm 2.06 a$ & $7.28 \pm 0.31 \mathrm{a}$ & $6.72 \pm 0.45 \mathrm{a}$ \\
\hline \multicolumn{8}{|l|}{ Analysis of Variance } \\
\hline \multicolumn{2}{|l|}{ Cultivars (C) } & \multicolumn{3}{|c|}{$P<0.01$} & \multicolumn{3}{|c|}{$P<0.01$} \\
\hline \multicolumn{2}{|l|}{$\mathrm{Fe}$} & \multicolumn{3}{|c|}{$P<0.01$} & \multicolumn{3}{|c|}{ NS } \\
\hline \multicolumn{2}{|l|}{ Sb Speciation (Sb) } & \multicolumn{3}{|c|}{$P<0.01$} & \multicolumn{3}{|c|}{$P<0.01$} \\
\hline \multicolumn{2}{|l|}{$\mathrm{C} \times \mathrm{Fe}$} & \multicolumn{3}{|c|}{ NS } & \multicolumn{3}{|c|}{$P<0.01$} \\
\hline \multicolumn{2}{|l|}{$\mathrm{C} \times \mathrm{Sb}$} & \multicolumn{3}{|c|}{$P<0.01$} & \multicolumn{3}{|c|}{ NS } \\
\hline \multicolumn{2}{|l|}{$\mathrm{Fe} \times \mathrm{Sb}$} & \multicolumn{3}{|c|}{ NS } & \multicolumn{3}{|c|}{ NS } \\
\hline \multicolumn{2}{|l|}{$\mathrm{C} \times \mathrm{Fe} \times \mathrm{Sb}$} & \multicolumn{3}{|c|}{ NS } & & \multicolumn{2}{|l|}{$P<0.05$} \\
\hline
\end{tabular}


when $\mathrm{Sb}$ (III) was supplied. Cultivars of NK got the highest $\mathrm{Sb}$ concentration in root with $\mathrm{Sb}(\mathrm{V})$ supplied (Table 2).

Antimony distribution in different plant components

Cultivars, $\mathrm{Sb}$ species and $\mathrm{Fe}^{2+}$ concentrations in the pretreatment solutions had significant effects on percentages of $\mathrm{Sb}$ in different plant components $(P<$ 0.01 , Table 3). Percentage of antimony in shoots was significantly lower than those in DCB extracts and roots, and accounted for up to $1-11 \%$ of the total $\mathrm{Sb}$.

There was a significantly positive correlation between the amount of iron plaque and the percentages of $\mathrm{Sb}$ in DCB-extracts. However, the percentages of $\mathrm{Sb}$ in roots and shoots decreased when $\mathrm{Fe}^{2+}$ concentrations in pretreatment solution increased with $\mathrm{Sb}(\mathrm{III})$ or $\mathrm{Sb}(\mathrm{V})$ supplied for three cultivars (Table 3 ).

The percentage of $\mathrm{Sb}$ in DCB-extracts with $\mathrm{Sb}(\mathrm{V})$ supplied was lower than that with $\mathrm{Sb}(\mathrm{III})$ supplied. Whereas, percentages of $\mathrm{Sb}$ in roots and shoots with $\mathrm{Sb}(\mathrm{V})$ supplied were higher compared with those with $\mathrm{Sb}$ (III) supplied for three cultivars.

Cultivars had no effect on the Sb distribution in different plant components with $\mathrm{Sb}(\mathrm{V})$ supplied (Table 3). But different conclusions were found in $\mathrm{Sb}(\mathrm{III})$ treatment. The general orders of $\mathrm{Sb}$ distribution followed the ranking of $\mathrm{YD}<\mathrm{NK}<\mathrm{JH} \quad(\mathrm{Sb}$ percentage in DCB-extracts), $\mathrm{YD}>\mathrm{NK}>\mathrm{JH}$ ( $\mathrm{Sb}$ percentage in roots) $(P<0.01)$. The percentages of $\mathrm{Sb}$ in shoot were not affected by cultivars treated with $\mathrm{Sb}$ (III).

\section{Discussion}

The DCB-Sb concentrations correlated significantly with the amounts of iron plaque on the root surfaces for the 3 cultivars that were exposed to different forms of antimony (Fig. 2; Fig. 3). This result was similar to As observed in the previous studies both in rice and other plant species (Greipsson 1995; Liu et al. 2004a, b). The highest $\mathrm{Sb}$ concentration in DCB-extracts was 2-4 times higher than the lowest concentration in DCB-extracts $(\mathrm{Fe} 0)$, which means $\mathrm{Fe}$ plaque can accumulate much more antimony on the rice root surface. The similar results were observed from other elements and plant species. Zhang et al. (1998) found that iron plaque on root surfaces could accumulate $\mathrm{Zn}$. Ye et al. (2001) reported that $\mathrm{Cu}$ concentrations in the DCB-extracts of Typha latifolia increased with increasing $\mathrm{Fe}$ plaque on the root surfaces. Nickel concentrations on the root surfaces of Typha latifolia with iron plaque were also significantly higher than those without iron plaque (Ye et al., 1997).

The DCB-extracted $\mathrm{Sb}$ on the root surfaces still correlated significantly with the antimony speciation. $\mathrm{Sb}(\mathrm{III})$ was more easily accumulated on the surfaces by the Fe plaque than $\mathrm{Sb}(\mathrm{V})$ (highest concentrations for YD: $838 \mathrm{mg} \mathrm{kg}^{-1}$ vs. $313 \mathrm{mg} \mathrm{kg}^{-1}$; NK: $1,832 \mathrm{mg} \mathrm{kg}^{-1}$ vs. $374 \mathrm{mg} \mathrm{kg}-1$; JH: $2,532 \mathrm{mg} \mathrm{kg}^{-1}$ vs. $253 \mathrm{mg} \mathrm{kg}^{-1}$, respectively) (Table 1). However, Liu et al. (2005) reported that arsenic concentrations in Fe plaque on the roots treated with arsenate were significantly higher than with arsenite. The possible reason was the different chemical properties of $\mathrm{Sb}(\mathrm{III})$ (supplied with $\mathrm{KSbC}_{4} \mathrm{H}_{4} \mathrm{O}_{7} \cdot 1 / 2 \mathrm{H}_{2} \mathrm{O}$ ) and $\mathrm{Sb}(\mathrm{V}$ ) (supplied with $\mathrm{KSb}(\mathrm{OH})_{6}$ ) in this study. Kamenar et al. (1969) reported that $\mathrm{Sb}(\mathrm{III})$ (supplied with $\left.\mathrm{KSbC}_{4} \mathrm{H}_{4} \mathrm{O}_{7} \cdot 1 / 2 \mathrm{H}_{2} \mathrm{O}\right)$ exists as $\left[\mathrm{Sb}_{2}\left(\mathrm{C}_{4} \mathrm{H}_{2} \mathrm{O}_{6}\right)_{2}\right]^{2-}$ unit in aqueous solution with two negative charges. According to the $\mathrm{pE}-\mathrm{pH}$ diagram for the Sb-O-H (Susan et al. 2010), the predominate species of antimonate is $\mathrm{Sb}(\mathrm{OH})_{6}{ }^{-}$at $\mathrm{pH}>3$ only with one negative charge. Therefore, the predominant species of $\mathrm{Sb}(\mathrm{III})$ and $\mathrm{Sb}(\mathrm{V})$ in solution are different from arsenate and arsenite which are $\mathrm{H}_{2} \mathrm{AsO}_{4}{ }^{-}$and $\mathrm{H}_{3} \mathrm{AsO}_{3}{ }^{0}$ at same $\mathrm{pH}$ range (Sadiq et al. 1983).

The $\mathrm{Sb}$ concentrations in the rice roots treated with $\mathrm{Sb}(\mathrm{III})$ were slightly higher than that with $\mathrm{Sb}(\mathrm{V})$ (Table 2), but this is not as significant as the $\mathrm{Sb}$ concentrations in the DCB-extracts (Table 1). The formation and amounts of iron plaque on rice roots had no significantly effect on the uptake of $\mathrm{Sb}$ (III) in roots (Table 2), but significantly increased the absorption of $\mathrm{Sb}$ (III) in roots (Table 2). This meant iron plaque was the source of $\mathrm{Sb}(\mathrm{V})$ transfer into the roots, but not for $\mathrm{Sb}(\mathrm{III})$. Liu et al. (2005) demonstrated that arsenic concentrations in roots were significantly lower when arsenate was supplied than when arsenite was supplied with Fe plaque. Liu et al. (2007) found that the formation of iron plaque on the roots of rice significantly decreased the Cd concentrations in roots. Zhang et al. (1998) suggested that $\mathrm{Zn}$ concentrations in rice roots increased and then decreased with increasing the amounts of Fe plaque on the root surfaces. 


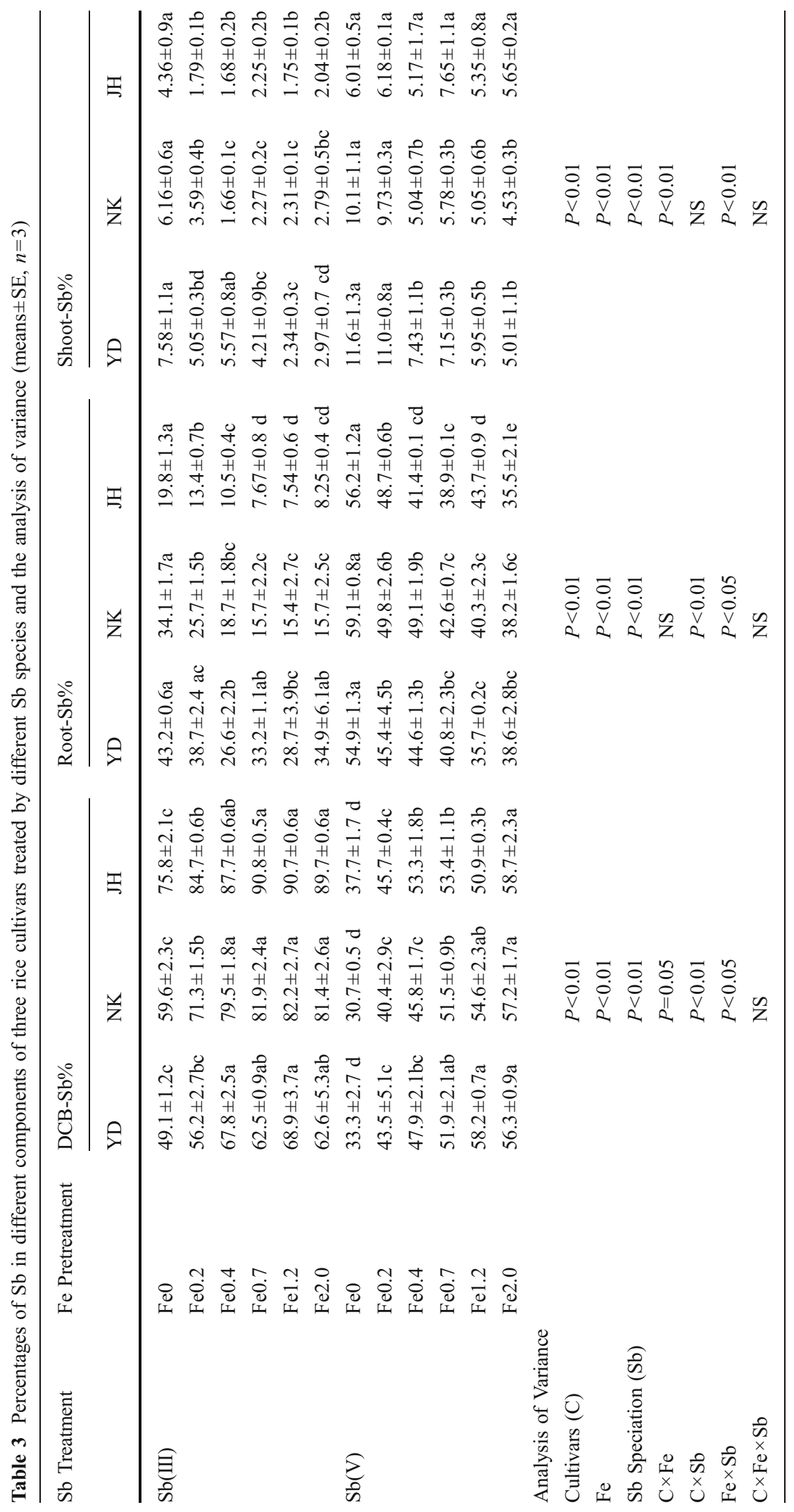


The proportions of $\mathrm{Sb}$ in DCB-extracts and roots were significantly higher than those in shoots (Table 3 ), indicating that iron plaque and roots systems were the main barriers to antimony translocation. Fe plaque formation increased the percentage of antimony in DCB-extracts and roots, but decreased that in shoots (Table 3), indicating that $\mathrm{Fe}$ plaque may act as a 'buffer' to prevent $\mathrm{Sb}$ translocation from roots to shoots. Percentages of $\mathrm{Sb}$ in different components were also significantly affected by $\mathrm{Sb}$ species. The proportion of $\mathrm{Sb}$ in DCB-extracts treated with $\mathrm{Sb}$ (III) was much higher than that treated with $\mathrm{Sb}(\mathrm{V})$, whereas the percentages of $\mathrm{Sb}$ in roots and shoots showed the opposite trend. So we can conclude that $\mathrm{Sb}$ (III) translocation was more easily affected by iron plaque than $\mathrm{Sb}(\mathrm{V})$ translocation. Liu et al. (2004a, b) reported that more than $80 \%$ of the As existed in DCB-extracts with arsenate supplied, and $\mathrm{As}(\mathrm{V})$ was more easily accumulated in $\mathrm{Fe}$ plaque on the root surfaces than As(III). Liu et al. (2007) found that root systems absorbed much $\mathrm{Cd}$ and root tissue was the main barrier to $\mathrm{Cd}$ translocation, the proportion of $\mathrm{Cd}$ in roots accounted for approximate $65 \%$ of total Cd uptake.

\section{Conclusions}

$\mathrm{Sb}$ accumulated on the root surface were largely associated with the amounts of iron plaque when both $\mathrm{Sb}(\mathrm{III})$ and $\mathrm{Sb}(\mathrm{V})$ supplied. Fe plaque accumulates more $\mathrm{Sb}$ in $\mathrm{Sb}(\mathrm{III})$ treatment than $\mathrm{Sb}(\mathrm{V})$ exposure. $\mathrm{Sb}$ concentrations in roots and shoots with $\mathrm{Sb}$ (III) supplied were slightly higher than those treated with $\mathrm{Sb}(\mathrm{V})$. JH cultivar exhibited the highest $\mathrm{Sb}$ concentrations in DCBextracts but the lowest $\mathrm{Sb}$ concentrations in shoots.

Acknowledgments Seeds of three rice (Oryza sativa L.) cultivars (Yangdao 6(YD), Nongken 57(NK), Jiahua 1(JH)) were obtained from Professor Shen Qirong, Nanjing Agricultural University, and Dr. Cheng Wangda, Jiaxing Academy of Agricultural Sciences.This study was supprted by National Natural Science Foundation of China (20720102042), the Ministry of Science and Technology, China (2009AA06Z402) and Chinese Academy of Sciences (KZCX2-YW-Q02-06).

\section{References}

Armstrong W (1967) The oxidising activity of roots in waterlogged soils. Physiol Plant 20:920-926
Armstrong J, Armstrong W (2005) Rice: sulfide-induced barriers to root radial oxygen loss, $\mathrm{Fe}^{2+}$ and water uptake, and lateral root emergence. Ann Bot 96:625-638

Baroni F, Boscagli A, Protano G, Riccobono F (2000) Antimony accumulation in Achillea ageratum, Plantago lanceolata and Silene vulgaris growing in an old Sbmining area. Environ Pollut 109:347-352

Batty LC, Baker AJM, Wheeler BD, Curtis CD (2000) The effect of $\mathrm{pH}$ and plaque on the uptake of $\mathrm{Cu}$ and $\mathrm{Mn}$ in Phragmites australis (Cav) Trin ex Steudel. Ann Bot 86:647-653

Casiot C, Ujevic M, Munoz M, Seidel JL, Elbaz-Poulichet F (2007) Antimony and arsenic mobility in a creek draining an antimony mine abandoned 85 years ago (upper Orb basin, France). Appl Geochem 22:788-798

Chen Z, Zhu YG, Liu WJ, Meharg AA (2005) Direct evidence showing the effect of root surface iron plaque on arsenite and arsenate uptake into rice (Oryza sativa L.) roots. New Phytol 165:91-97

Colmer TD (2003) Aerenchyma and an inducible barrier to radial oxygen loss facilitate root aeration in upland, paddy and deep-water rice (Oryza sativa L.). Ann Bot 91:301309

Council of the European Communities (1976) Council Directive 76/464/EEC of 4 May 1976 on pollution caused by certain dangerous substances discharged into the aquatic environment of the community. Official Journal L 129:2329

Filella M, Belzile N, Chen Y (2002) Antimony in the environment: a review focused on natural waters I Occurrence. Earth-Sci Rev 57:125-176

Filella M, Williams PA, Belzile N (2009) Antimony in the environment: knowns and unknowns. Environ Chem 6:95-105

Flynn HC, Meharg AA, Bowyer PK, Paton GI (2003) Antimony bioavailability in mine soils. Environ Pollut 124:93-100

Gebel T (1997) Arsenic and antimony: comparative approach on mechanistic toxicology. Chem Biol Interact 107:131144

Greipsson S (1995) Effect of iron plaque on roots of rice on growth of plants in excess zinc and accumulation of phosphorus in plants in excess copper or nickel. J Plant Nutr 18:1659-1665

Hammel W, Debus R, Steubing L (2000) Mobility of antimony in soil and its availability to plants. Chemosphere 41:1791-1798

He MC, Yang JR (1999) Effects of different forms of antimony on rice during the period of germination and growth and antimony concentration in rice tissue. Sci Total Environ 243-244:149-155

Irina S, Roza B, Andrew H (2011) Bioavailability and toxicity of antimony. J Geochem Explor 110:40-45

Kamenar B, Grdenic D, Prout CK (1969) The crystal and molecular structure of racemic di-1-tartrato-diantimonate (III) trihydrate (racemic 'tartar emetic'). Acta Cryst B26:181-188

Krachler M, Shotyk W, Emons H (2001) Digestion procedures for the determination of antimony and arsenic in small amounts of peat samples by hydride generation-atomic absorption spectrometry. Anal Chim Acta 432:307-314 
Liu WJ, Zhu YG, Smith FA, Smith SE (2004a) Do phosphorus nutrition and iron plaque alter arsenate (As) uptake by rice seedlings in hydroponic culture? New Phytol 162:481-488

Liu WJ, Zhu YG, Smith FA, Smith SE (2004b) Do iron plaque and cultivars affect arsenate uptake and translocation by rice seedlings (Oryza sativa L.) grown in solution culture? J Exp Bot 55:1707-1713

Liu WJ, Zhu YG, Smith FA (2005) Effects of iron and manganese plaques on arsenic uptake of by rice seedlings (Oryza sativa L.) grown in solution culture supplied with arsenate and arsenite. Plant Soil 277:127-138

Liu HJ, Zhang JL, Zhang FS (2007) Role of iron plaque in Cd uptake by and translocation within rice (Oryza sativa L.) seedlings grown in solution culture. Environ Exp Bot 59:314-320

Miravet R, Bonilla E, López-Sánchez JF, Rubio R (2005) Antimony speciation in terrestrial plants Comparative studies on extraction methods. J Environ Monit 7:12071213

Murciego AM, Sanchez AG, Gonzalez MAR, Gil EP, Gordillo CT, Fernandez JC, Triguero TB (2007) Antimony distribution and mobility in topsoils and plants (Cytisus striatus, Cistus ladanifer and Dittrichia viscosa) from polluted Sb-mining areas in Extremadura (Spain). Environ Pollut 145:15-21

Rish MA (2004) Antimony, in elements and their compounds in the environment 659-670. Weinheim, Wiley-VHC
Sadiq M, Zaidi TH, Mian AA (1983) Environmental behavior of arsenic in soils: theoretical. Water Air Soil Pollut 20:369-377

Susan C, Wilson PV, Lockwood PM, Ashley MT (2010) The chemistry and behavior of antimony in the soil environment with comparisons to arsenic: a critical review. Environ Pollut 158:1169-1181

Sun GX, Williams PN, Carey AM, Zhu YG, Deacon C, Raab A, Feldmann J, Islam RM, Meharg AA (2008) Inorganic arsenic in rice bran and its products are an order of magnitude higher than in bulk grain. Environ Sci Technol 42:7542-7546

USEPA (1999) United States Environmental Protection Agency, Integrated Risk Information System (IRIS) on Antimony. National Center for Environmental Assessment, Office of Research and Development, Washington, DC

Wang TG, Peverly JH (1999) Iron oxidation states on root surfaces of a wetland plant (Phragmites australis). Soil Sci Soc Am J 63:247-252

Ye ZH, Baker AJM, Wong MH, Willis AJ (1997) Copper and nickel uptake, accumulation and tolerance in Typha latifolia with and without iron plaque on the root surface. New Phytol 136:481-488

Ye ZH, Cheung KC, Wong MH (2001) Copper uptake in Typha latifolia as affected by iron and manganese plaque on the root surface. Can J Bot 79:314-320

Zhang XK, Zhang FS, Mao DR (1998) Effect of iron plaque outside roots on nutrient uptake by rice (Oryza sativa L.): zinc uptake by Fe-deficient rice. Plant Soil 202:33-39 